\title{
Is there a Predictive Value of Hemoglobin A1C for Complications of Cardiac Surgery?
}

\author{
Selen Ozturk², Ilyas Kayacoglu², Yavuz Sensoz², Safa Ozcelik², Yucesin Arslan² and Ibrahim Oztürk ${ }^{1}$ \\ ${ }^{1}$ Department of Cardiovascular Surgery, Goztepe Education and Research Hospital, Istanbul, Turkey \\ ${ }^{2}$ Department of Anesthesiology, Goztepe Education and Research Hospital, Istanbul, Turkey
}

\begin{abstract}
Objective: To investigate the effect of preoperative hemoglobin Alc levels for the complications of cardiac surgery.

Study Design: Meta-analysis.

Place of Study: Siyami Ersek Chest and Cardiovascular Surgery Education and Research Hospital, Istanbul, Turkey.

Methodology: PubMed, Scopus, Web of Science and Ovid electronic databases were used. The studies were included the recorded preoperative levels of hemoglobin A1C and postoperative complications developed after cardiac surgery. Results of the studies were evaluated, based on either random or fixed effect model, according to presence of heterogeneity $\left(I^{2}>25 \%\right)$.

Results: In total, 2,312 articles were obtained. After reviewing the articles, 33 articles covering 3500 patients meeting the inclusion criteria were included. The results pointed out that there was a relationship between preoperative hemoglobin Alc levels and mediastinitis, stroke, pneumonia, sepsis, renal failure and mortality. Heterogeneity was observed for myocardial infarction, atrial fibrillation and multiorgan failure $\left(I^{2}>25 \%\right)$.

Conclusion: Preoperative hemoglobin AlC levels were associated with development of mediastinitis, stroke, pneumonia, sepsis, renal failure and mortality after cardiac surgery.
\end{abstract}

Key Words: Hemoglobin AlC, Cardiac surgery, Complication, Meta-analysis.

How to cite this article: Ozturk S, Kayacoglu I, Sensoz Y, Ozcelik S, Arslan Y, Oztürk I. Is there a Predictive Value of Hemoglobin AlC for Complications of Cardiac Surgery?. J Coll Physicians Surg Pak 2021; 31(06):686-693.

\section{INTRODUCTION}

Diabetes mellitus (DM) is one of the most observed systemic diseases in surgical patients. In current guideline of American Diabetes Association (ADA), four criteria have been determined for diagnosis of DM. ${ }^{1}$ Fasting plasma glucose $\geq 126 \mathrm{mg} / \mathrm{dL}$; two hour plasma glucose during oral glucose tolerance test $\geq 200$ $\mathrm{mg} / \mathrm{dL}$; a random plasma glucose $\geq 200 \mathrm{mg} / \mathrm{dL}$; hemoglobin Alc $(\mathrm{HbAlc}) \geq 6.5 \%$. One of these criteria is adequate for diagnosis of $\mathrm{DM}$. HbAlc is an indirect measure of average glucose levels. It must be taken into consideration that many factors may affect hemoglobin glycation (hemodialysis, pregnancy, age, race, anemia etc.) as well as glycemia. ${ }^{1}$

In a recent meta-analysis, Zheng et al. demonstrated that $\mathrm{HbAlc} \mathrm{levels} \mathrm{were} \mathrm{associated} \mathrm{with} \mathrm{non-fatal} \mathrm{myocardial} \mathrm{infarc-}$ tion after percutaneous coronary intervention. ${ }^{2}$ On the other hand, Qi et al. found a relationship between elevated $\mathrm{HbAlc}$ and atrial fibrillation. ${ }^{3}$

Correspondence to: Dr. Ibrahim Oztürk, Department of Anesthesiology, Goztepe Education and Research Hospital, Istanbul, Turkey

E-mail: drozturk28@gmail.com

Received: July 29, 2020; Revised: February 20, 2021;

Accepted: March 22, 2021

DOI: https://doi.org/10.29271/jcpsp.2021.06.686
In literature, there is only one meta-analysis, which evaluated the importance of preoperative HbAlc for outcomes (complications) in cardiac surgical patient population. ${ }^{4}$ The main issue of the studies including $\mathrm{HbAlc}$ is the various cut-off points that becloud the results. Moreover, various causes of increase in $\mathrm{HbAlc}$ make interpretation difficult. Therefore, the authors aimed to investigate the relationship between $\mathrm{HbAlc}$ and outcomes in cardiac surgery.

\section{METHODOLOGY}

Databases were screened in accordance with the guidelines published by Moher et al. ${ }^{5}$ The authors performed database screening to investigate the importance of preoperative $\mathrm{HbAlc}$ levels for determining the postoperative complications following cardiac surgery procedures in adult patients. The researchers investigated the database up to $11^{\text {th }}$ June 2020 . There was no limitation determined for the publication date of the articles. PubMed, Scopus, Ovid and Web of Science were used as electronic databases. There was no screening performed apart from the electronic database. However, articles that may be relevant were investigated in the reference sections of the articles. Keywords used were (cardiac surgery, heart surgery, valve surgery, complication, hemoglobin Alc, glycated hemoglobin, glycosylated hemoglobin). The articles published in other languages were not included. 
Table I: Summary of studies.

\begin{tabular}{|c|c|c|c|c|c|c|c|c|c|}
\hline Author & Year & Country & $\begin{array}{l}\text { No of } \\
\text { patients }\end{array}$ & $\begin{array}{l}\text { DM } \\
(\%)\end{array}$ & $\begin{array}{l}\text { CABG } \\
(\%)\end{array}$ & Outcomes & $\begin{array}{l}\text { Cut-off } \\
\text { point } \\
\text { (\%) }\end{array}$ & $\begin{array}{l}\text { Type of } \\
\text { surgery }\end{array}$ & $\begin{array}{l}\text { Study } \\
\text { design }\end{array}$ \\
\hline Almogati et al. & 2019 & Saudi & 305 & 81.6 & 100 & $\begin{array}{l}\text { Mediastinitis, POAF, RF, } \\
\text { Mortality }\end{array}$ & 7 & CABG & $\mathrm{R}$ \\
\hline Bardia et al. & 2017 & USA & 763 & 19 & 0 & $\begin{array}{l}\text { Mediastinitis, POAF, RF, MI, Re- } \\
\text { op, stroke, CT, Mortality }\end{array}$ & 6.5 & valve & $P$ \\
\hline Biskupski et al. & 2014 & Poland & 350 & 100 & 40.5 & $\begin{array}{l}\text { RF, MI, Re-op, stroke, LCOS, } \\
\text { Mortality }\end{array}$ & 7 & combined & $\mathrm{R}$ \\
\hline Engoren et al. & 2014 & USA & 880 & 47.15 & 100 & $\begin{array}{l}\text { Mediastinitis, POAF, RF, MI, } \\
\text { stroke, sepsis, Mortality }\end{array}$ & 7 and 6 & CABG & $\mathrm{R}$ \\
\hline Faritous et al. & 2014 & Iran & 216 & 35.2 & 100 & $\begin{array}{l}\text { RF, MI, CT, sepsis, MOF, } \\
\text { Mortality }\end{array}$ & 7 & CABG & $P$ \\
\hline Finger et al. & 2016 & USA & 511 & 34.2 & 50.6 & $\begin{array}{l}\text { Mediastinitis, RF, Re-op, sepsis, } \\
\text { mortality }\end{array}$ & 7 & combined & $\mathrm{R}$ \\
\hline Gumuş et al. & 2013 & Turkey & 510 & 40.2 & 92.4 & $\begin{array}{l}\text { Mediastinitis, POAF, RF, Re-op, } \\
\text { CT, LCOS, GIS, mortality. }\end{array}$ & 6 & combined & $R$ \\
\hline Halkos et al.** & 2008 & USA & 3089 & 40.1 & 100 & $\begin{array}{l}\text { Mediastinitis, POAF, RF, MI, } \\
\text { mortality }\end{array}$ & 7 & CABG & $P$ \\
\hline Kim et al. & 2019 & South Korea & 503 & 100 & 100 & $\begin{array}{l}\text { Mediastinitis, RF, Re-op, stroke, } \\
\text { mortality }\end{array}$ & 7 & CABG & $\mathrm{R}$ \\
\hline Knapik et al. & 2011 & Poland & 735 & 100 & 100 & $\begin{array}{l}\text { RF, MI, stroke, sepsis, MOF, } \\
\text { mortality }\end{array}$ & 7 & CABG & $\mathrm{R}$ \\
\hline Matsuura et al. & 2009 & Japan & 101 & 100 & 100 & $\begin{array}{l}\text { Mediastinitis, POAF, RF, Re-op, } \\
\text { mortality }\end{array}$ & 6.5 & CABG & $\mathrm{R}$ \\
\hline Narayan et al. & 2017 & India & 4678 & 65 & 100 & Mediastinitis, POAF, RF, GIS & 6.5 & CABG & $\mathrm{R}$ \\
\hline Nicolini et al. & 2018 & Multicenter & 2606 & 36.1 & 100 & $\begin{array}{l}\text { Mediastinitis, RF, stroke, } \\
\text { mortality }\end{array}$ & 7 & CABG & $P$ \\
\hline Oezkur et al. & 2015 & Germany & 307 & 34.5 & 100 & $\mathrm{RF}$, mortality & 6 & combined & $\mathrm{P}$ \\
\hline Ramadan et al. & 2018 & Egypt & 80 & 100 & 100 & $\begin{array}{l}\text { Mediastinitis, POAF, RF, MI, } \\
\text { stroke, LCOS, mortality }\end{array}$ & 7 & CABG & $P$ \\
\hline Robich et al. & 2019 & USA & 6415 & 34.2 & 100 & $\begin{array}{l}\text { POAF, RF, Re-op, stroke, LCOS, } \\
\text { mortality }\end{array}$ & 6.5 & CABG & $\mathrm{R}$ \\
\hline Santos et al. & 2015 & Argentina & 96 & 100 & 100 & $\begin{array}{l}\text { Mediastinitis, RF, MI, stroke, } \\
\text { sepsis, mortality }\end{array}$ & 7 & CABG & $P$ \\
\hline Sato et al. & 2010 & Japan & 130 & 100 & 60 & $\begin{array}{l}\text { Mediastinitis, RF, stroke, sepsis, } \\
\text { mortality }\end{array}$ & 6.5 & combined & $P$ \\
\hline Strahan et al. & 2013 & Australia & 712 & 100 & 100 & $\begin{array}{l}\text { RF, MI, Re-op, stroke, MOF, } \\
\text { mortality }\end{array}$ & 7 & CABG & $\mathrm{R}$ \\
\hline Subramaniam et al. & 2014 & USA & 1461 & 38.6 & 74.1 & $\begin{array}{l}\text { Mediastinitis, POAF, RF, MI, Re- } \\
\text { op, stroke, CT, mortality }\end{array}$ & 6.5 & combined & $P$ \\
\hline Tsuruta et al. & 2011 & Japan & 306 & 100 & 100 & $\begin{array}{l}\text { Mediastinitis, POAF, RF, MI, Re- } \\
\text { op, stroke, LCOS, GIS }\end{array}$ & 6.5 & CABG & $\mathrm{P}$ \\
\hline Alserius et al. & 2008 & Sweden & 605 & 27 & 100 & Mediastinitis, Mortality & 6 and 7 & CABG & $\mathrm{P}$ \\
\hline Fohl et al. & 2013 & USA & 626 & 100 & 59 & Mediastinitis, & 7 & Combined & $\mathrm{R}$ \\
\hline Gatti et al. & 2017 & Italy & 2130 & 35.1 & 100 & Mediastinitis, & 7 & CABG & $P$ \\
\hline Göksedef et al. & 2010 & Turkey & 148 & 35.3 & 70.8 & Mediastinitis, mortality & 7 & Combined & $P$ \\
\hline Halkos et al.* & 2008 & USA & 5199 & 25.8 & 100 & Mediastinitis, & 7 & CABG & $\mathrm{P}$ \\
\hline Arslan et al. & 2015 & Turkey & 180 & 66.6 & 100 & $\begin{array}{l}\text { Re-op, Pneumonia, POAF, } \\
\text { Mediastinitis, mortality }\end{array}$ & 7 & CABG & $\mathrm{R}$ \\
\hline Elsayed et al. & 2019 & Egypt & 80 & 100 & 100 & RF, MI, LCOS, mortality & 8.6 & CABG & $P$ \\
\hline Elghoneimy et al. & 2020 & Saudi & 104 & 100 & 100 & Re-op, mortality & 8.5 & CABG & $\mathrm{R}$ \\
\hline Joshi et al. & 2020 & India & 350 & 48 & 66.28 & $\begin{array}{l}\text { Re-op, RF, Mediastinitis, } \\
\text { mortality }\end{array}$ & 7 & Combined & $R$ \\
\hline Islam et al. & 2019 & Bangladesh & 60 & 100 & 100 & $\begin{array}{l}\text { POAF, RF, Mediastinitis, LCOS, } \\
\text { mortality }\end{array}$ & 7 & CABG & $\mathrm{P}$ \\
\hline Khan et al. & 2019 & USA & 1133 & 48.3 & 100 & Sepsis, Pneumonia, mortality & 7 & CABG & $\mathrm{R}$ \\
\hline Gür et al. & 2020 & Turkey & 118 & 100 & 100 & Pneumonia, POAF, mortality & 7 & CABG & $\mathrm{R}$ \\
\hline
\end{tabular}

Selection of studies was planned according to the PRISMA guidelines (Participants, Intervention, Comparison, Outcomes and Study design). ${ }^{6}$

All studies (retrospective or prospective) were included. Inclusion criteria were clinical human study, published in English language regarding with control subjects on any open cardiac surgery. Exclusion criteria were: experimental studies, case reports or case series, non-surgical interventions, studies without control groups, editorials and reviews, non-cardiac surgery. Studies that were related to the investigation topic but did not provide information about cut-off point of preoperative $\mathrm{HbAlc}$ were not included in the analysis. The intervention group was designed as $\mathrm{HbAlc}>$ cut-off point; and control group was designed as $\mathrm{HbAlc}<$ cut-off point; for our analysis. Additionally, articles presenting the relevant data as figures or graphs were excluded from the analysis.

The researchers recorded data from the articles (first author name, year of publication, event and sample number in each group, research design) independently. The authors included the articles which recorded the levels of $\mathrm{HbAlc}$ as percentage and classified the groups according to cut-off point of HbAlc. Grouping in studies with more than one threshold value was resolved by consensus. Disagreements related to data and articles were resolved by compromise. Data were entered into the meta-analysis programme as those with the relevant events in each group and the total number of patients in groups. 
Table II: PRISMA checklist.

\begin{tabular}{|c|c|c|c|}
\hline Section/topic & No. & Checklist item & $\begin{array}{l}\text { Reported on } \\
\text { page }\end{array}$ \\
\hline \multicolumn{4}{|l|}{ Title } \\
\hline Title & 1 & Identify the report as a systematic review, meta-analysis, or both. & 1 \\
\hline \multicolumn{4}{|c|}{ (2) } \\
\hline Structured summary & 2 & $\begin{array}{l}\text { Provide a structured summary including, as applicable: background; objectives; data sources; study eligibility } \\
\text { criteria, participants, and interventions; study appraisal and synthesis methods; results; limitations; } \\
\text { conclusions and implications of key findings; systematic review registration number. }\end{array}$ & 2 \\
\hline \multicolumn{4}{|c|}{ (1) } \\
\hline Rationale & 3 & Describe the rationale for the review in the context of what is already known. & 3 \\
\hline Objectives & 4 & $\begin{array}{l}\text { Provide an explicit statement of questions being addressed with reference to participants, interventions, } \\
\text { comparisons, outcomes, and study design (PICOS). }\end{array}$ & 3 \\
\hline \multicolumn{4}{|c|}{. } \\
\hline Protocol and registration & 5 & $\begin{array}{l}\text { Indicate if a review protocol exists, if and where it can be accessed (e.g., Web address), and, if available, } \\
\text { provide registration information including registration number. }\end{array}$ & - \\
\hline Eligibility criteria & 6 & $\begin{array}{l}\text { Specify study characteristics (e.g., PICOS, length of follow-up) and report characteristics (e.g., years } \\
\text { considered, language, publication status) used as criteria for eligibility, giving rationale. }\end{array}$ & 4 \\
\hline Information sources & 7 & $\begin{array}{l}\text { Describe all information sources (e.g., databases with dates of coverage, contact with study authors to } \\
\text { identify additional studies) in the search and date last searched. }\end{array}$ & 4 \\
\hline Search & 8 & $\begin{array}{l}\text { Present full electronic search strategy for at least one database, including any limits used, such that it could } \\
\text { be repeated. }\end{array}$ & 4 \\
\hline Study selection & 9 & $\begin{array}{l}\text { State the process for selecting studies (i.e., screening, eligibility, included in systematic review, and, if } \\
\text { applicable, included in the meta-analysis). }\end{array}$ & 4 \\
\hline Data collection process & 10 & $\begin{array}{l}\text { Describe method of data extraction from reports (e.g., piloted forms, independently, in duplicate) and any } \\
\text { processes for obtaining and confirming data from investigators. }\end{array}$ & 5 \\
\hline Data items & 11 & $\begin{array}{l}\text { List and define all variables for which data were sought (e.g., PICOS, funding sources) and any assumptions } \\
\text { and simplifications made. }\end{array}$ & 5 \\
\hline $\begin{array}{l}\text { Risk of bias in individual } \\
\text { studies }\end{array}$ & 12 & $\begin{array}{l}\text { Describe methods used for assessing risk of bias of individual studies (including specification of whether this } \\
\text { was done at the study or outcome level), and how this information is to be used in any data synthesis. }\end{array}$ & 5 \\
\hline Summary measures & 13 & State the principal summary measures (e.g., risk ratio, difference in means). & 5 \\
\hline Synthesis of results & 14 & $\begin{array}{l}\text { Describe the methods of handling data and combining results of studies, if done, including measures of } \\
\text { consistency }\left(e . g ., I^{2}\right) \text { for each meta-analysis. }\end{array}$ & 5 \\
\hline Risk of bias across studies & 15 & $\begin{array}{l}\text { Specify any assessment of risk of bias that may affect the cumulative evidence (e.g., publication bias, } \\
\text { selective reporting within studies). }\end{array}$ & 5 \\
\hline Additional analyses & 16 & $\begin{array}{l}\text { Describe methods of additional analyses (e.g., sensitivity or subgroup analyses, meta-regression), if done, } \\
\text { indicating which were pre-specified. }\end{array}$ & 5 \\
\hline \multicolumn{4}{|c|}{ ( } \\
\hline Study selection & 17 & $\begin{array}{l}\text { Give numbers of studies screened, assessed for eligibility, and included in the review, with reasons for } \\
\text { exclusions at each stage, ideally with a flow diagram. }\end{array}$ & 6 \\
\hline Study characteristics & 18 & $\begin{array}{l}\text { For each study, present characteristics for which data were extracted (e.g., study size, PICOS, follow-up } \\
\text { period) and provide the citations. }\end{array}$ & 6 \\
\hline Risk of bias within studies & 19 & Present data on risk of bias of each study and, if available, any outcome level assessment (see item 12). & 6 \\
\hline Results of individual studies & 20 & $\begin{array}{l}\text { For all outcomes considered (benefits or harms), present, for each study: (a) simple summary data for each } \\
\text { intervention group (b) effect estimates and confidence intervals, ideally with a forest plot. }\end{array}$ & 6 \\
\hline Synthesis of results & 21 & Present results of each meta-analysis done, including confidence intervals and measures of consistency. & 6 \\
\hline Risk of bias across studies & 22 & Present results of any assessment of risk of bias across studies (see Item 15). & 7 \\
\hline Additional analysis & 23 & $\begin{array}{l}\text { Give results of additional analyses, if done (e.g., sensitivity or subgroup analyses, meta-regression [see Item } \\
\text { 16]). }\end{array}$ & $6-7$ \\
\hline \multicolumn{4}{|l|}{ Discussion } \\
\hline Summary of evidence & 24 & $\begin{array}{l}\text { Summarize the main findings including the strength of evidence for each main outcome; consider their } \\
\text { relevance to key groups (e.g., healthcare providers, users, and policy makers). }\end{array}$ & 8 \\
\hline Limitations & 25 & $\begin{array}{l}\text { Discuss limitations at study and outcome level (e.g., risk of bias), and at review-level (e.g., incomplete } \\
\text { retrieval of identified research, reporting bias). }\end{array}$ & 10 \\
\hline Conclusions & 26 & $\begin{array}{l}\text { Provide a general interpretation of the results in the context of other evidence, and implications for future } \\
\text { research. }\end{array}$ & 11 \\
\hline \multicolumn{4}{|c|}{ 2 } \\
\hline Funding & 27 & $\begin{array}{l}\text { Describe sources of funding for the systematic review and other support (e.g., supply of data); role of funders } \\
\text { for the systematic review. }\end{array}$ & no \\
\hline
\end{tabular}

Statistical analysis used the Jamovi ${ }^{\circledR}$ and Open MetaAnalyst ${ }^{\circledR}$ programmes. The Odds ratio (OR) and $95 \%$ confidence interval (CI) were applied. Heterogeneity was assessed with the $\mathrm{I}^{2}$ statistic. While heterogeneity was accepted as significant, if $I^{2}$ $\geq 25 \%$. Determination of the cause of heterogeneity was evaluated with analysis of moderators. Meta-analysis used fixed or random models. In the presence of heterogeneity $\left(I^{2}>25 \%\right)$, the random effects model was used; and in the absence of heterogeneity $\left(\mathrm{I}^{2}<25 \%\right)$, the fixed effects model was used. Publication bias was assessed, according to the Begg test with $p<0.05$ indicating statistical significance.

\section{RESULTS}

A total of 2,312 records were obtained at electronic databases. Eighteen hundred and fifty records were removed because of duplication. Review of titles and abstracts of 462 articles excluded, another 369 records were irrelevant. A total of 93 full-text articles assessed for eligibility. Eventually, 33 research articles comprising 35,487 patients were included in quantitative synthesis. ${ }^{7-39}$ The flowchart for database screening is shown (Figure 1). The demographic data and features of the articles were reviewed (Table I). Thirteen recorded complications included atrial fibrillation (AF), myocardial infarction (MI), low cardiac output syndrome (LCOS), gastrointestinal complications, cardiac tamponade, multiorgan failure (MOF), mediastinitis, stroke, pneumonia, sepsis, renal failure, re-operation and mortality.

There was a relationship between preoperative $\mathrm{HbAlc}$ levels and mediastinitis (OR: $1.08,95 \% \mathrm{Cl}: 0.88-1.28$ and $p<0.001$ ), stroke (OR: $0.42,95 \% \mathrm{Cl}: 0.14-0.71$ and $\mathrm{p}=0.004$ ), pneumonia 
(OR: $0.45,95 \% \mathrm{Cl}: 0.14-0.75$ and $\mathrm{p}=0.004$ ), sepsis (OR: 0.57 , 95\% Cl: $0.02-1.11$ and $p=0.04$ ), renal failure (OR: $0.49,95 \%$ $\mathrm{Cl}: 0.40-0.58$ and $\mathrm{p}<0.001)$ and mortality (OR: $0.289,95 \% \mathrm{Cl}$ : $0.088-0.490$ and $p=0.005)$. The other complications such as atrial fibrillation (OR: $-0.01,95 \% \mathrm{Cl}:-0.10-0.07$ and $\mathrm{p}=0.77$ ), myocardial infarction (OR: $0.57,95 \% \mathrm{Cl}:-0.07-1.20$ and $\mathrm{p}=0.079$ ), cardiac tamponade (OR: $0.03,95 \% \mathrm{Cl}:-0.75-0.81$ and $p=0.93$ ), re-operation (OR: $-0.20,95 \% \mathrm{Cl}:-0.46-0.05$ and $\mathrm{p}=0.12$ ), low cardiac output syndrome (OR: $0.09,95 \% \mathrm{Cl}$ : $-0.12-0.30$ and $p=0.41$ ), gastrointestinal system complications (OR: $-0.004,95 \% \mathrm{Cl}:-0.38-0.38$ and $\mathrm{p}=0.08$ ), and multi-organ failure (OR: $0.77,95 \% \mathrm{Cl}:-1.40-2.94$ and $p=0.49$ ) were not related with $\mathrm{HbAlc}$ levels. The forest plots of analyses represented in Figures 2a-b, 3a-b and 4a-b.

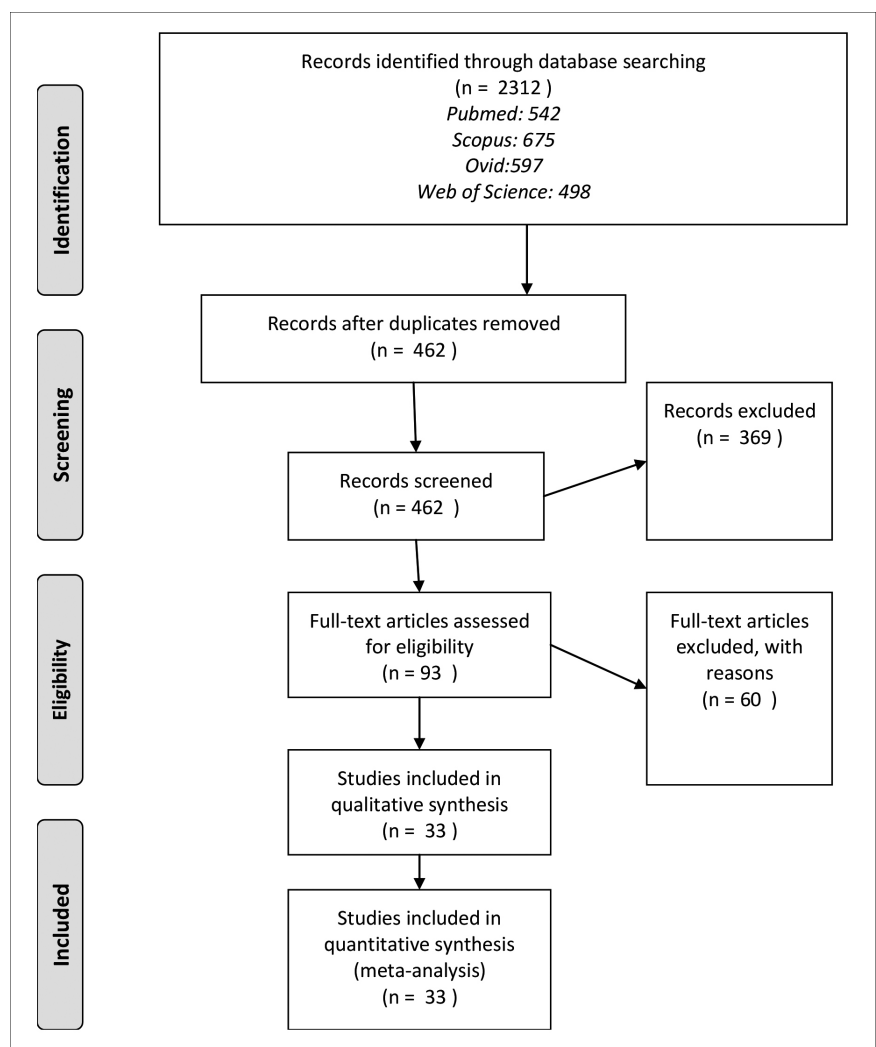

Figure 1: Flow diagram of database search.

When the heterogeneity between the studies were analysed, heterogeneity was observed in articles including atrial fibrillation (Q: 18.65 , df: $13, \mathrm{I}^{2}=30.3 \%, \mathrm{P}=0.13$ ), myocardial infarction (Q: 17.99 , df: $11, \mathrm{I}^{2}=41.18, \mathrm{P}=0.08$ ), and multi-organ failure (Q: 5.10 , df: $2, I^{2}=64.34 \%, P=0.08$ ). $I^{2}$ was greater than $25 \%$ in those trials. The cause of heterogeneity was investigated, it appeared as preoperative levels of $\mathrm{HbAlc}$ for $\mathrm{MI}\left(\mathrm{I}^{2}\right.$ for level $6.5 \%=0$ and for level $7 \%=72.3$ in $\mathrm{MI}$ ). We analysed $\mathrm{HbAlc}$ cut-off point, design of trials (prospective/retrospective) and types of surgery (coronary artery bypass grafting/valve /combined) as moderators. However, the cause of heterogeneity in trials, including AF, could not be determined. Analysis for MOF could not be done because of small number of trials about this outcome.

Assessment results of possible publication bias, according to the Begg test, were not significant for $\mathrm{MI}$ and MOF (tau ${ }^{2}$ $>0.05$ ). The checklist of the review is presented in Table II.
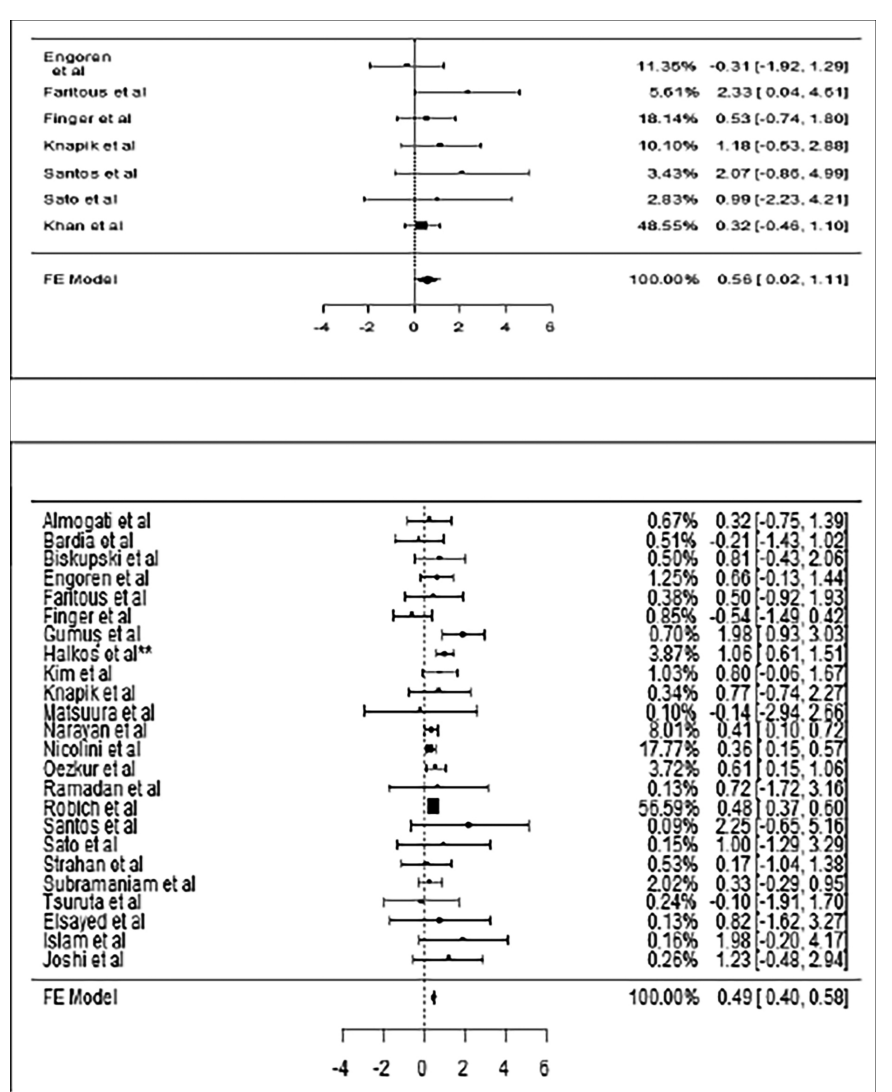

Figure $2(a, b)$ : Forest plots of sepsis (a) and renal failure (b) analyses.

\begin{tabular}{lll}
\hline Bardia et al \\
Engoren et al \\
Faritous et al \\
Finger et al \\
Sato et al \\
Subramaniam et al \\
Tsuruta et al \\
Arslan et al \\
Gür et al \\
Khan et al
\end{tabular}

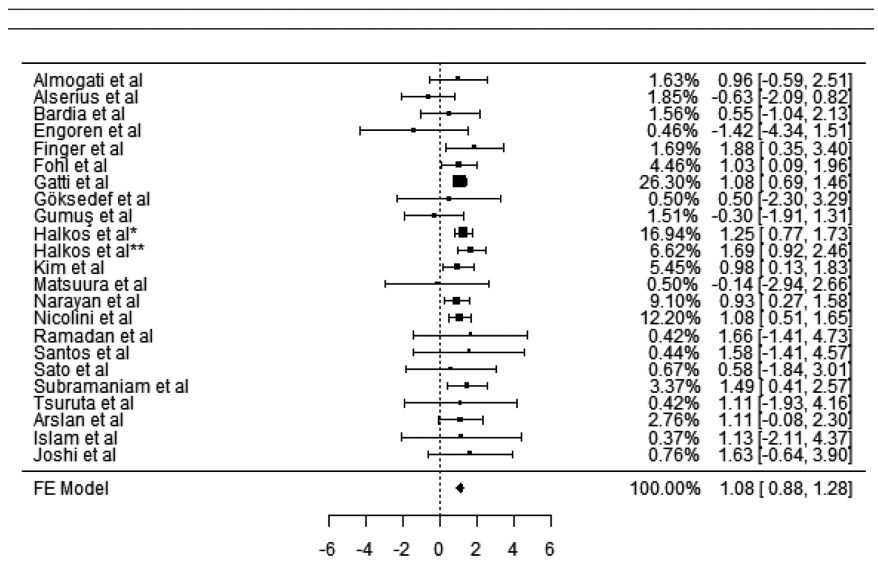

Figure $3(a, b)$ : Forest plots of pneumonia (a) and mediastinitis (b) analyses. 


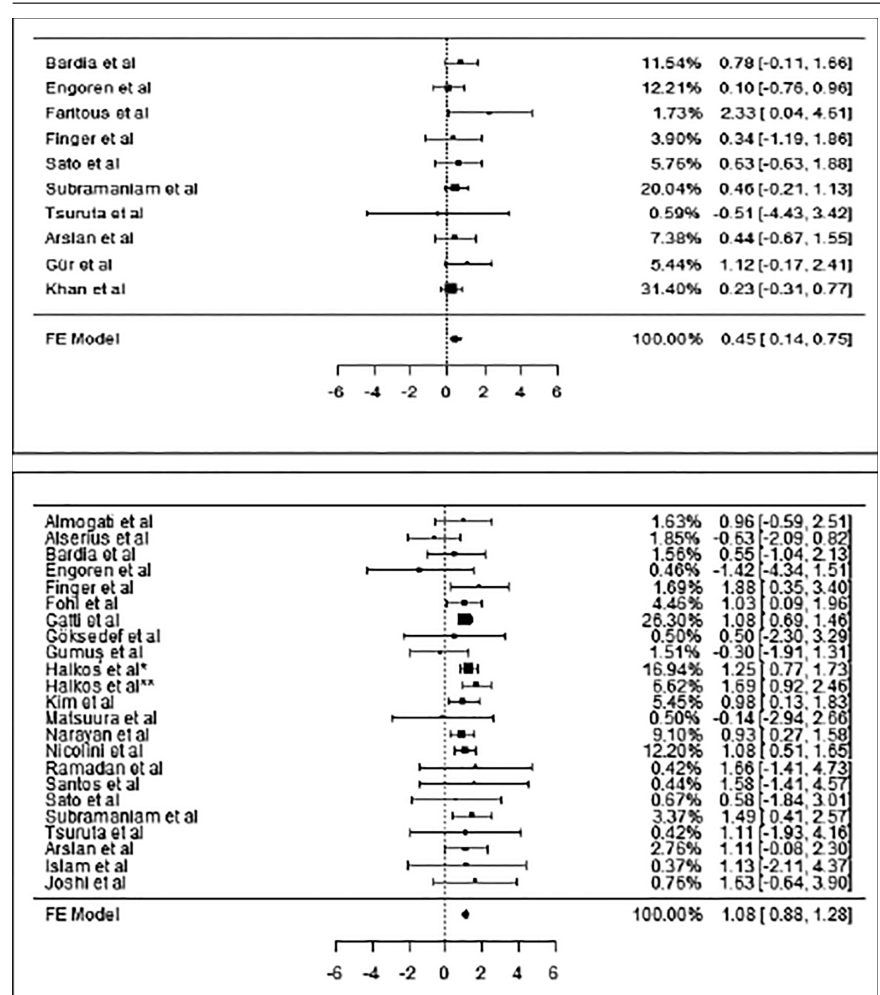

Figure $4(a, b)$ : Forest plots of stroke (a) mortality (b) analyses.

\section{DISCUSSION}

Data was obtained from the articles recorded 13 outcomes. It is found that preoperative high $\mathrm{HbAlc}$ levels were related with only seven complications (mediastinitis, stroke, pneumonia, sepsis, renal failure and mortality). There was no relationship between $\mathrm{HbAlc}$ levels and $\mathrm{AF}, \mathrm{MI}$, cardiac tamponade, LCOS, gastrointestinal complication and MOF. Heterogeneity was observed for trials about MI, AF and MOF. The main reason was $\mathrm{HbAlc}$ levels for MI. However, the authors could not apply subgroup analysis for MOF, because of small number of studies (only three trials were included) and could not determine a reason as a cause of heterogeneity for studies including AF.

The cut-off value of $\mathrm{HbAlc}$ is recommended as $6.5 \%$ (48 $\mathrm{mmol} / \mathrm{mol}$ ) by ADA in recent guideline. ${ }^{1}$ However for different countries, there are many different results. Mousavi et al. found $80 \%$ sensitivity and $76 \%$ specifity for $5.05 \%$ for gestational DM at Iranian population..$^{40}$ In Chinese adult patients, three authors found three different values in different trials. Wang et al. obtaind $6.5 \%$ as a result, while Liu et al. and Liang et al. found as $6.3 \%$ and $5.9 \%$, respectively. ${ }^{41-43}$ On the other hand, Do Vale Moreira et al. observed the cut-off point as $\geq 6.8 \%$ for Brazilian adult patients in 714 patients. ${ }^{44}$

In this analysis, most of the preoperative HbAlc cut-off points were $7 \%$ in included articles. The others were $6 \%$, $6.5 \%, 8.5 \%$ or $8.6 \%$. At this point, it is important for standardisation of trials, the cut-off value must be $6.5 \%$, recommended by ADA.
Two points draw the attention. First, the direct cardiovascular complications such as AF and MI were not related with $\mathrm{HbAlc}$ levels. Moreover, a second point all of the infectious complications (sepsis, pneumonia and mediastinitis) were related.

The most agreed risk factors of AF are known as age, obesity, smoking, gender, sedentary lifestyle, DM and obstructive sleep apnea. ${ }^{45}$ In a large population based study, Kim et al. analysed $9,797,418$ patients. ${ }^{46}$ They observed that both DM and concomitant increase in body mass index have rised the risk of new onset AF. Especially, duration of DM ( $\geq 5$ years) and obesity showed synergistic effect and provided the possible risk of new onset AF the highest. In contrast to previous classical knowledge, there was no correlation between DM and MI. This data is compatible with a meta-analysis performed by Zhang et al. ${ }^{47}$

The second point of this analysis about infectious complications, was a predictable result. Zhang et al. meta-analysis demonstrated that sternal infections were associated with DM after cardiac surgery procedures. ${ }^{47}$ That result is correlated with a more recent meta-analysis applied by Martin et al. ${ }^{48}$ who found that DM was associated with increased risk of surgical site infection after surgery. However, DM was not a risk factor for ventilator associated pneumonia after cardiac surgery. ${ }^{49}$

Biancari et al., in a more recent meta-analysis, evaluated the association of $\mathrm{HbAlc}$ and sternal wound infection after cardiac surgery. ${ }^{4}$ They included 17,609 patients from 14 trials and showed the increased risk of sternal wound infection because of preoperative $\mathrm{HbAlc}$ levels over $6-7 \%$.

In a retrospective study, Hudson et al. found higher blood glucose levels among the patients with high $\mathrm{HbAlc} .^{50} \mathrm{High}$ $\mathrm{HbAlc}$ level was associated with 30-day mortality, acute kidney injury. However, they found no relation between $\mathrm{HbAlc}$ and infections. They used $6 \%$ as the cut-off point for HbAlc. On the other hand, the result for mortality was similar with Hudson et $a l^{50}$

There are some controversial points about reliability of HbAlc against plasma glucose levels. Some authors prefer HbAlc compared with plasma glucose, because microangiopathic complications are strongly associated with $\mathrm{HbAlc}$, it is better related with cardiovascular disease, fasting is not needed for assessment, acute situations such as stress, diet or smoking does not affect, it has a greater pre-analytical stability, and biological variability is lower. ${ }^{51}$ The other authors argue against $\mathrm{HbAlc}$. According to them, $\mathrm{HbAlc}$ is a poor sensitivity for DM diagnosis, it is poor marker for important pathophysiological abnormalities, standardisation of $\mathrm{HbAlc}$ assay is poor, in many subjects HbAlc assay is unreliable, percentage of $\mathrm{Hbalc}$ is not effective for prediction of $D M$, the trials about prevention of DM are not based on $\mathrm{HbAlc}$, and diagnosis of DM in $\sim 60 \%$ by $\mathrm{HbAlc}$ can resulted with a delay. ${ }^{51}$ 
This meta-analysis is different from the others in literature ${ }^{2-4}$ with the classification of groups. The authors investigated the outcomes by the cut-off points as percentage not by the mean \pm standard deviation values between the groups.

The main limitation of this analysis is the absence of standardisation of $\mathrm{HbAlc}$ levels in individual trials. It has ranged from $6 \%$ to $8.6 \%$. The other limitations are inclusion of only the English language articles using different types of study designs instead of randomised controlled trials only; surgical procedures were not standardised as isolated CABG or valve surgery.

\section{CONCLUSION}

There was a relationship between preoperative $\mathrm{HbAlc}$ high levels and mediastinitis, stroke, pneumonia, sepsis, renal failure and mortality after cardiac surgery. It is thought by the authors that the studies must be standardised due to $\mathrm{HbAlc}$ cut-off point as $6.5 \%$ according to ADA recommendations and also they must be larger randomised controlled trials. On the other hand, different HbAlc threshold values for different complications should be investigated and evaluated separately for each outcome.

\section{CONFLICT OF INTEREST:}

The authors declared no conflict of interest.

\section{AUTHORS' CONTRIBUTION:}

SO, IK, YS, SO, YA, IO: Concept, design, data collection, analysis, literature search, writing.

\section{REFERENCES}

1. American diabetes association. 2. Classification and diagnosis of diabetes: standards of medical care in diabetes 2020. Diabetes Care 2020; 43(Suppl 1):S14-S31. doi: 10.2337/dc20-S002.

2. Zheng J, Cheng J, Zhang Q, Qi C, Wang T, Xiao X. Association between glycosylated hemoglobin level and cardiovascular outcomes in diabetic patients after percutaneous coronary intervention. Medicine (Baltimore) 2016; 95(19):e3696. doi: 10.1097/MD.0000000000003696.

3. Qi W, Zhang N, Korantzopoulos P, Letsas, KP, Cheng M, Di F, et al. Serum glycated hemoglobin level as a predictor of atrial fibrillation: A systematic review with meta-analysis and metaregression. PLoS One 2017; 12(3):e0170955. doi: 10.1371/journal.pone.0170955.

4. Biancari F, Giordano S. Glycated hemoglobin and the risk of sternal wound infection after adult cardiac surgery: A systematic review and meta-analysis. Semin Thorac Cardiovasc Surg 2019; 31(3):465-7. doi: 10.1053/j. semtcvs.2019.02.029

5. Moher D, Shamseer L, Clarke M, Ghersi D, Liberati A, Petticrew $M$, et al. Preferred reporting items for systematic review and meta-analysis protocols (PRISMA-P) 2015 statement. Syst Rev 2015; 4(1):1. doi: 10.1186/2046-4053-4-1.

6. Centre for reviews and dissemination. Systematic Reviews: CRD's Guidance for Undertaking Reviews in Health Care. York: University of York; 2006.
7. Almogati JG, Ahmed EO. Glycated hemoglobin as a predictor of the length of hospital stay in patients following coronary bypass graft surgery in the Saudi population. Braz J Cardiovasc Surg 2019; 34(1):28-32. doi: 10.21470/ 1678-97412018-0202.

8. Alserius $\mathrm{T}$, Anderson RE, Hammar N, Nordqvist $\mathrm{T}$, Ivert $\mathrm{T}$. Elevated glycosylated haemoglobin ( $\mathrm{HbAlc}$ ) is a risk marker in coronary artery bypass surgery. Scand Cardiovasc J 2008; 42(6):392-8. doi: 10.1080/14017430801942393.

9. Bardia A, Khabbaz K, Mueller A, Mathur P, Novack V, Talmor D, et al. The association between preoperative hemoglobin alc and postoperative glycemic variability on 30-day major adverse outcomes following isolated cardiac valvular surgery. Anesth Analg 2017; 124(1):16-22. doi: 10.1213/ANE.0000 000000001715.

10. Biskupski A, Waligórski S, Kowalik B, Żych A, Sielicki P, Mirecki $O$, et al. Glycated hemoglobin $\mathrm{HbAlc}$ - a new risk marker for the outcome of cardiac surgery? Kardiochir Torakochirurgia Pol 2014; 11(1):7-11. doi: 10.5114/kitp.2014.41922.

11. Engoren M, Schwann TA, Habib RH. Elevated hemoglobin Alc is associated with readmission but not complications. Asian Cardiovasc Thorac Ann 2014; 22(7):800-6. doi: 10.1177/ 0218492313515895.

12. Finger B, Brase J, He J, Gibson WJ, Wirtz K, Flynn BC. Elevated hemoglobin alc is associated with lower socioeconomic position and increased postoperative infections and longer hospital stay after cardiac surgical procedures. Ann Thorac Surg 2017; 103(1):145-51. doi: 10. 1016/j.athoracsur. 2016.05.092.

13. Faritous Z, Ardeshiri M, Yazdanian F, Jalali A, Totonchi Z, Azarfarin R. Hyperglycemia or high hemoglobin A1C: Which one is more associated with morbidity and mortality after coronary artery bypass graft surgery? Ann Thorac Cardiovasc Surg 2014; 20(3):223-8. doi: 10.5761/atcs.oa.13.02282.

14. Fohl AL, Butler SO, Patil PV, Zrull CA, Kling-Colson S, Dubois E, et al. The association between hemoglobin $A 1 C$ values and deep sternal wound infections in diabetes patients undergoing cardiac surgery. Cardiovasc Endocrinol 2013; 2:15-22

15. Gatti G, Perrotti A, Reichart D, Maschietto L, Onorati F, Chocron $S$, et al Hemoglobin and risk of sternal wound infection after isolated coronary surgery. Circ 2016; 22:36-43.

16. 16 Gumus F, Polat A, Sinikoglu SN, Yektas A, Erkalp K, Alagol A. Use of a lower cut-off value for $\mathrm{HbAlc}$ to predict postoperative renal complication risk in patients undergoing coronary artery bypass grafting. J Cardiothorac Vasc Anesth 2013; 27(6):1167-73. doi: 10.1053/j.jvca.2013.02.030.

17. Göksedef D, Ömeroğlu SN, Yalvaç EŞD, Bitargil M, İpek G. Is elevated $\mathrm{HbAlc}$ a risk factor for infection after coronary artery bypass grafting surgery? Turk Gogus Kalp Dama 2010; 18:252-8.

18. Halkos ME, Puskas JD, Lattouf OM, Kilgo P, Kerendi F, Song HK. Elevated preoperative hemoglobin Alc level is predictive of adverse events after coronary artery bypass surgery. J Thorac Cardiovasc Surg 2008; 136(3):631-40. doi: 10.1016/j.jtcvs. 2008.02.091.

19. Halkos ME, Thourani VH, Lattouf OM, Kilgo P, Guyton RA, Puskas JD. Preoperative hemoglobin A1C predicts sternal wound infection after coronary artery bypass surgery with bilateral versus single internal thoracic artery grafts. Innovations (Phila) 2008; 3(3):131-8. doi: 10.1097/ IMI.0b013e31 819165 ec.

20. Kim HJ, Shim JK, Youn YN, Song JW, Lee H, Kwak YL. Influence 
of preoperative hemoglobin Alc on early outcomes in patients with diabetes mellitus undergoing off-pump coronary artery bypass surgery. J Thorac Cardiovasc Surg 2019; 1:30300-9.

21. Knapik P, Cieśla D, Filipiak K, Knapik M, Zembala M. Prevalence and clinical significance of elevated preoperative glycosylated hemoglobin in diabetic patients scheduled for coronary artery surgery. Eur J Cardiothorac Surg 2011; 39(4):484-9. doi: 10.1016/j.ejcts.2010.07.037.

22. Matsuura K, Imamaki M, Ishida A, Shimura H, Niitsuma $Y$, Miyazaki M. Off-pump coronary artery bypass grafting for poorly controlled diabetic patients. Ann Thorac Cardiovasc Surg 2009; 15(1):18-22.

23. Nicolini F, Santarpino G, Gatti G, Reichart D, Onorati F, Faggian $G$, et al. Utility of glycated hemoglobin screening in patients undergoing elective coronary artery surgery: Prospective, cohort study from the E-CABG registry. Int J Surg 2018; 53:354-9. doi: 10.1016/j.ijsu.2018.04.021.

24. Narayan P, Kshirsagar SN, Mandal CK, Ghorai PA, Rao YM, Das $D$, et al. Preoperative glycosylated hemoglobin: A risk factor for patients undergoing coronary artery bypass. Ann Thorac Surg 2017; 104(2):606-12. doi: 10.1016/j.athoracsur.2016.

25. Ramadan M, Abdelgawad A, Elshemy A, Sarawy E, Emad A, Mazen $M$, et al. Impact of elevated glycosylated hemoglobin on hospital outcome and 1 year survival of primary isolated coronary artery bypass grafting patients. Egypt Heart J 2018; 70(2):113-8. doi: 10.1016/j.ehj.2017.09.002.

26. Oezkur M, Wagner M, Weismann D, Krannich JH, Schimmer C, Riegler $C$, et al. Chronic hyperglycemia is associated with acute kidney injury in patients undergoing CABG surgery-a cohort study. BMC Cardiovasc Disord 2015; 12:15:41. doi: 10.1186/s12872-015-0028-y.

27. Robich MP, Iribarne A, Leavitt BJ, Malenka DJ, Quinn RD, Olmstead EM, et al. Northern New England cardiovascular disease study group. Intensity of glycemic control affects longterm survival after coronary artery bypass graft surgery. Ann Thorac Surg 2019; 107(2):477-84. doi: 10.1016/j. athoracsur.2018.07.078.

28. Santos JM, Favaloro RR, Lowenstein D, Sanabria H, Raffaelli $H$, Hershson A. Medium-term glycemic control in diabetics before coronary bypass surgery. Medicina (B Aires) 2015; 75(5):277-81.

29. Strahan S, Harvey RM, Campbell-Lloyd A, Beller E, Mundy J, Shah P. Diabetic control and coronary artery bypass: Effect on short-term outcomes. Asian Cardiovasc Thorac Ann 2013; 21(3):281-7. doi: 10.1177/0218492312451983.

30. Subramaniam B, Lerner A, Novack V, Khabbaz K, Paryente-Wiesmann $M$, Hess $P$, et al. Increased glycemic variability in patients with elevated preoperative $\mathrm{HbAlC}$ predicts adverse outcomes following coronary artery bypass grafting surgery. Anesth Analg 2014; 118(2):277-87. doi: 10.1213/ANE. 0000000000000100.

31. Sato H, Carvalho G, Sato T, Lattermann R, Matsukawa T, Schricker T. The association of preoperative glycemic control, intraoperative insulin sensitivity, and outcomes after cardiac surgery. J Clin Endocrinol Metab 2010; 95(9):4338-44. doi: 10.1210/jc.2010-0135.

32. Tsuruta R, Miyauchi K, Yamamoto T, Dohi S, Tambara K, Dohi $T$, et al. Effect of preoperative hemoglobin Alc levels on longterm outcomes for diabetic patients after off-pump coronary artery bypass grafting. J Cardiol 2011; 57(2):181-6. doi: 10.1016/j.jjcc.2010.11.003.
33. Arslan U, Memetoğlu ME, Kutlu R, Erbasan O, Tort M, Çalık ES, et al. Preoperative $\mathrm{Hbalc}$ level in prediction of short-term morbidity and mortality outcomes following coronary artery bypass grafting surgery. Russian Open Medical J 2015; 4:e0204.

34. Gür AK, Şahinalp Ş, Eker E, Ünal H. Effect of preoperative HBA1C levels on postoperative acute renal failure in diabetic patients undergoing coronary bypass surgery. Medical Science 2020; 24;526-32.

35. Elsayed ASI, Eid KRA. Tracing the proposed adverse effects of higher values of glycosylated hemoglobin ( $\mathrm{HbAlc}$ ) in tightly-controlled diabetic patients undergoing primary CABG. Int J Cardiovascular Thoracic Surger 2019; 5:31-40.

36. Elghoneimy YF, Nashy MR, Othman SA, Almarri NM, Alruwaili $A A$, Alotaibi AR, et al. Which level of preoperative glycated haemoglobin ( $\mathrm{HbAlC}$ ) affect early morbidity and mortality after cardiac surgery? AMJ 2020; 13:32-40.

37. Joshi H, Kumara V, Rai G. Bishnoi AK. Study of association of preoperative glycosylated haemoglobin level and outcome after cardiac surgery. Sri Lankan J Anaesthesiol 2020; 28; 14-8.

38. Khan MR, Khan H, Wahab A, Chaudhary S, Munir A, Youssef J, et al. Effect of glycemic control on mortality and infections in patients undergoing coronary artery bypass grafting: A Genesee County experience. J Community Hospital Internal Medicine Perspectives 2019; 9(2):74-9. doi: 10.1080/ 20009666.2019.1581044.

39. Islam S, Quashem MA, Hossain A, Pervin R, Shahidullah A, Ahmed T, et al. Early Outcome of Coronary Artery Bypass Graft Surgery in Patients with Preoperative Elevated Level of HbAlc with Diabetes Mellitus. Bangladesh Heart J 2019; 34(2):92-9. doi.org/10.3329/bhj.v34i2.44439.

40. Mousavi SN, Kamali K, Mirbazel M, Jameshorani M. The best cut-off value for hbalc as a screening tool in iranian women with gestational diabetes mellitus. J Family Reprod Health 2017; 11(1):37-42.

41. Wang B, Liu MC, Li XY, Liu XH, Feng QX, Lu L, et al. Cutoff Point of $\mathrm{HbAlc}$ for Diagnosis of Diabetes Mellitus in Chinese Individuals. PLoS One 2016; 11(11):e0166597. doi: 10.1371/journal.pone.0166597.

42. Liu Y, Xiao X, Sun C, Tian S, Sun Z, Gao Y, et al. Ideal glycated hemoglobin cut-off points for screening diabetes and prediabetes in a Chinese population. J Diabetes Investig 2016; 7(5):695-702. doi: 10.1111/jdi.12498.

43. Liang K, Wang C, Yan F, Wang L, He T, Zhang X, et al. HbAlC cutoff point of $5.9 \%$ better identifies high risk of progression to diabetes among chinese adults: Results from a retrospective cohort study. J Diabetes Res 2018; 13:7486493.

44. Do Vale Moreira NC, Montenegro RM, Meyer HE, Bhowmik B, Mdala I, Siddiquee T, et al. Glycated hemoglobin in the diagnosis of diabetes mellitus in a semi-urban brazilian population. Int J Environ Res Public Health 2019; 16(19):3598. doi: 10.3390/ijerph16193598.

45. Staerk L, Sherer JA, Ko D, Benjamin EJ, Helm RH. Atrial Fibrillation: Epidemiology, Pathophysiology, and Clinical Outcomes. Circ Res 2017; 120(9):1501-17. doi: 10.1161/ CIRCRESAHA.117.309732.

46. Kim YG, Han KD, Choi JI, Boo KY, Kim DY, Oh SK, et al. The impact of body weight and diabetes on new-onset atrial fibrillation: A nationwide population based study. Cardiovasc Diabetol 2019; 18(1):128. doi: 10.1186/s12933-019-0932-z. 
47. Zhang $X$, Wu Z, Peng X, Wu A, Yue Y, Martin J, et al. Prognosis of diabetic patients undergoing coronary artery bypass surgery compared with nondiabetics: A systematic review and meta-analysis. J Cardiothorac Vasc Anesth 2011; 25(2): 288-98. doi: 10.1053/j.jvca.2010.09.021.

48. Martin ET, Kaye KS, Knott C, Nguyen H, Santarossa M. Diabetes and risk of surgical site infection: A systematic review and meta-analysis. Infect Control Hosp Epidemiol 2016; 37(1):88-99. doi: 10.1017/ice.2015.249.

49. He S, Chen B, Li W, Yan J, Chen L, Wang X, et al. Ventilator-associated pneumonia after cardiac surgery: A meta-analysis and systematic review. I Thorac Cardiovasc Surg 2014; 148(6):3148-55. doi: 10.1016/j.jtcvs.2014.07.107.

50. Hudson CC, Welsby IJ, Phillips-Bute B, Mathew JP, Lutz A, Chad Hughes $G$, et al. Cardiothoracic anesthesiology research endeavors (C.A.R.E.) group. Glycosylated hemoglobin levels and outcome in non-diabetic cardiac surgery patients. Can J Anaesth 2010; 57(6):565-72. doi: 10.1007/s12630010-9294-4.

51. Bonora E, Tuomilehto J. The pros and cons of diagnosing diabetes with A1C. Diabetes Care 2011; 34Suppl 2(Suppl 2):S184-90. doi: 10.2337/dc11-s216. 